University of Wollongong

Research Online

Faculty of Engineering - Papers (Archive)

Faculty of Engineering and Information

Sciences

$1-1-2006$

\title{
Bisphenol A retention in the direct ultrafiltration of greywater
}

Long Nghiem

University of Wollongong, longn@uow.edu.au

Andrea Schaefer

University of Edinburgh

Nadine Oschmann

University of Applied Science - Berlin

Follow this and additional works at: https://ro.uow.edu.au/engpapers

Part of the Engineering Commons

https://ro.uow.edu.au/engpapers/3431

\section{Recommended Citation}

Nghiem, Long; Schaefer, Andrea; and Oschmann, Nadine: Bisphenol A retention in the direct ultrafiltration of greywater 2006, 233-243.

https://ro.uow.edu.au/engpapers/3431

Research Online is the open access institutional repository for the University of Wollongong. For further information contact the UOW Library: research-pubs@uow.edu.au 


\title{
Bisphenol A Retention in the Direct Ultrafiltration of Greywater
}

\author{
Submitted to \\ Journal of Membrane Science \\ March 2006; revised May 2006
}

\author{
ANDREA I. SCHÄFER ${ }^{1,2^{*}}$, LONG D. NGHIEM ${ }^{1}$, AND NADINE OSCHMANN $^{1,3}$ \\ ${ }^{1}$ Environmental Engineering, University of Wollongong, NSW 2522, Australia \\ ${ }^{2}$ School of Engineering and Electronics, The University of Edinburgh, Edinburgh, EH9 3JL, \\ United Kingdom \\ ${ }^{3}$ University of Applied Science, TFH Berlin, 13353 Berlin, Germany
}

* Corresponding author:

Andrea Schäfer, E-mail: Andrea.Schaefer@ed.ac.uk, Ph +44 1316507209 Fax +44 (0)131 6506781 


\section{Abstract}

Decentralised treatment is an increasing trend in the attempts to manage water more wisely in light of water restrictions, overconsumption and drought. Greywater is a fraction of household wastewater that offers the potential to be treated locally to be reused for garden irrigation, car washing and toilet flushing. In this paper the performance of submerged and direct ultrafiltration (UF) of synthetic greywater is investigated with regards to organic trace contaminant, namely Bisphenol A (BPA), and fouling. The synthetic greywater solution consisted of inorganic particulates (kaolin), organic fibres (cellulose), protein (casein), surfactant (sodium dodecyl sulphate, SDS), humic acid (HA), calcium, sodium chloride electrolyte and sodium bicarbonate buffer.

Results indicate that UF can remove $30-45 \%$ of BPA. This removal is attributed to partitioning of the compound to the membrane material, suspended and dissolved solids as well as the fouling layer. Humic acid and calcium were the main contributors to fouling, which also affected BPA retention. Fouling increased with an increase in HA concentration, which calcium contributed most to fouling at a concentration of about $0.5 \mathrm{mM}$. At higher concentration of calcium aggregation appeared to reduce fouling significantly.

The implications of this study are that trace contaminant-solute interactions play an important role for retention potential and this relationship offers room for optimization by selecting particulate additives with a high affinity for target compounds. This is of particular importance if such contaminants are a concern (which is dependent on the product water application) and in the absence of biological treatment which is in this case not desired. The separation of greywater into fractions of low and high strength is of advantage if this can eliminate the presence of humic substances.

Keywords: Greywater, Graywater, direct ultrafiltration, recycling, bisphenol A, trace contaminant. 


\section{INTRODUCTION}

\subsection{Greywater origin and composition}

Greywater is wastewater from the kitchen, bathroom (sink, bath and shower), laundry and any other non-toilet household wastewater. Due to the lack of urine and faeces in greywater, it is generally better accepted for recycling than blackwater which contains toilet waste. In the context of water restrictions, drought and water shortage greywater is considered for recycling for irrigation or in house purposes following decentralized treatment. Given the decentralized nature of the likely application such treatment needs to reliable and robust. Greywater characteristics vary significantly depending on the lifestyle and product selection of the household participants and fluctuations in a decentralized system can be severe, allowing significant periods of zero wastewater production to high flow of low strength greywater. The maintenance of some treatment systems, biological in particular, would give difficulties in light of fluctuating quantity and quality of the influent. Other treatment processes such as conventional filtration technology focuses primarily on particulate and biological contaminants.

Greywater accounts for about 65-75\% of water used in a household and the major contributors to this greywater load are summarized in Table 1. Greywater is generally characterised as a mixture of suspended solids (SS, particulates and colloids) and turbidity, chemical oxygen demand (COD), biochemical oxygen demand (BOD), total dissolved solids (TDS), on occasion total organic carbon (TOC) and the nutrients nitrogen (N) and phosphorous (P). A summary of greywater characteristics compared to blackwater is presented in Table 2. Due to the variation in greywater types, the fluctuations in quality are large and hence considerable overlap exists between black- and greywater. Ramon et al. [1] have in fact argued that the wastewater would be better classified as a function of pollution load rather than origin and hence suggesting the notion of low (bath, shower \& washbasin) and high (kitchen, washing machine \& dishwasher) strength greywater. This indicates that for research a variation of parameters over an expected concentration is justified.

The $\mathrm{pH}$ range of greywater (5-10.9) is more alkaline than domestic wastewater (5.9-7.7). The higher alkalinity of greywater originates mainly from laundry effluent. The highest values for suspended solids also originated from the laundry and kitchen, due to the presence of sand and clay from clothes or rinsing vegetables. COD, BOD, and TOC values differ widely within 
the greywater sources mostly due to a strong dependence on chemical products used. Proteins, carbohydrates and fats are common constituents [2]. The nitrogen concentration is lower in greywater, because urine as the main nitrogen source in domestic wastewater is not present in greywater. In greywater nitrogen originates from household cleaning products and from the kitchen sink. Proteins are also common ingredients in shampoos and have a high nitrogen content. The most commonly used proteins in shampoo are keratin and milk proteins. Phosphate originates mainly from laundry effluent.

In general greywater does not containing the right nutrient and trace element ratio required for biological treatment or a membrane bioreactor [3]. Surprisingly, no data on surfactant concentrations in domestic wastewater and greywater could be identified, even though they are common ingredients in household chemicals. Heavy metals in waste water originate mostly from industries, and usually not from household waste waters. But low concentrations of metals have been recorded in greywater by Erikson [4]. Since pathogens occur in greywater in much lower quantities than in domestic waste water and ultrafiltration (UF) removes pathogens from water reliably, the influence of pathogens in these experiments will not be investigated. The high loads of total and faecal coliforms in greywater according to some references are related to the introduction of faecal bacteria into the system during elderly/ baby washing and nappy changes.

\subsection{Specific organic greywater contaminants}

The organic contaminants which would predominate through the use of detergents, washing powders and personal care products has to date not been considered. The level of concern with regards to such contaminants is bifold. While detergents are rarely a concern if the recycled water is used for toilet flushing, in irrigation applications organic contaminants are posing a number of concerns. Firstly, additives to detergents play an important role in the transport of contaminants in soils and waterways, which is facilitated through rainfall and runoff, and secondly the potential of some contaminants to accumulate in soil, organisms and vegetation is to date poorly understood. Sumpter and Johnson [5] outline the issue of endocrine disrupting chemicals, such as Bisphenol A, in detail. Of particular interest to this study is the issue of 'pseudopersistence' the low level but continuous release of compounds as well as mixtures and

degradation products. In wastewater treatment the sorption of compounds to sludge and in the 
land application, the sorption to soil are important [6]. Similar interactions apply in greywater treatment where particulates and organic molecules will interact to some extend with trace organic contaminants which will affect the removal potential. In the environment, degradation following a number of pathways is important and some products may be more persistent than parent compounds. Degradation pathways are biological, hydrolysis and photochemical [7] with the proportion of each depending on chemical characteristics of the compounds as well as the nature of the environment.

Based on these observations from literature, a model greywater composition has been identified and will be described in the materials and methods section of this paper. In addition to the bulk constituents, another major concern are trace contaminants like endocrine disrupting chemicals (EDCs) in waste water [8]. However, no data is available with regards to the presence of trace organic compounds in greywater. Their presence would depend on the many constituents in personal care products and detergents as well as their degradation products. Bisphenol A was selected as a trace organic contaminant for this study due to its broad abundance in wastewater. Vilchez et al. [9] recorded concentration of BPA from 0.02 to $0.50 \mathrm{mg} / \mathrm{L}$ in wastewater, while Zafra et al. [10] recorded concentrations ranging from 0.01 to $2.50 \mathrm{mg} / \mathrm{L}$. BPA is a common name for 2,2-(4,4-dihydroxydiphenyl) propane which is used in polycarbonate plastics and epoxy resins. The structure of BPA and physicochemical characteristics in Table 3. BPA is one of the most produced chemicals worldwide and it is known to have endocrine disrupting potential [11]. BPA is known to quickly biodegrade and to adsorb to suspended solids and sediment in water. The pKa value of BPA is between 9.6 to 10.2 [12] which means that the molecule is neutral up to about $\mathrm{pH} 10$ and then has a negative charge.

\subsection{Greywater treatment}

Treating greywater prevents the dilution of trace contaminants excreted by humans in the blackwater which has the potential to increase the removal potential in sewage treatment for such compounds. Ramon et al. [1] have conducted experiments of low strength greywater treatment using ultra-and nanofiltration. Depending on the membranes used UF removed 45-70\% of COD as well as $92-97 \%$ of turbidity. As expected nanofiltration (NF) achieved $>90 \%$ dissolved organic removal and about 50\% TDS removal. For most reuse application NF may not be economic or necessary. Nghiem et al. [13] have investigated the removal mechanism of BPA in 
NF. The retention was $\mathrm{pH}$ dependent with retention of about $40 \%$ at $\mathrm{pH} 6$ when $\mathrm{BPA}$ is neutral and near $100 \%$ at $\mathrm{pH} 11$ when BPA is negatively charged. In a more applied study, Wintgens et al.[14] recorded retentions of nonylphenol (NP) and bisphenol A (BPA) in NF ranging between $70 \%$ and $100 \%$ and in a UF project, Schäfer et al. [15] found that particle-contaminant interaction like the absorption of natural hormones onto activated sludge and other particulates enhanced the retention of the hormones. Estrone retention in pure water ranged between 0-20\% depending on the membrane type, in solution containing NOM and kaolin retention was found between $10-30 \%$ and the highest retention was found during filtration of activated sludge (50$65 \%)$.

With regards to wastewater treatment and recycling most studies are applying a processes referred to as membrane bioreactor (MBR). In this process biological degradation and UF are combined. Fouling is a major issue in this process due to the generally high pollutant load. For example, Lodge et al.[16] have compared wastewater with greywater in UF following biological treatment and found similar fouling behaviour reasoning that the difference could be explained with a higher SS concentration in wastewater in that case. Yean et al . [17] used a MBR containing a submerged hollow fibre membrane for the treatment of household wastewater (including toilet waste), but this study mainly focused on nitrogen removal. The MBR was found to enhance nitrogen removal efficiency (83\%) compared to other biological nitrogen removal processes. Submerged UF membranes have been gaining more attention in water treatment applications since they are less energy consuming than crossflow and dead-end filtration membranes and they require little space $[18,19]$, which makes them also an interesting option for decentralized greywater recycling applications. Since nutrient deficiency in terms of both macro- and micronutrients which greywater exhibits potentially retard the efficacy of biological processes [3], including MBR, it might be of advantage to treat greywater purely by UF if sufficient organic matter can be removed.

In this study the direct UF as a physical separation process is studied. The effect of selected greywater compounds on the retention of a model trace organic contaminant, Bisphenol A, is investigated. Due to the design of the experiments of a relatively short term nature in the absence of microorganisms, retention of trace organics can be assumed to be due to sorption 
rather than degradation. The core interest of this study is to evaluate treatability of greywater on site with a physical membrane filtration technology that requires little maintenance.

\subsection{Ultrafiltration membrane fouling}

Different fouling mechanisms have been described in UF. While Jiang et al . [20] found pore blocking and cake formation the most important fouling mechanism in a MBR pilot plant, other studies have investigated colloidal, biological as well as organic fouling and their control $[18,21,22]$. While the mechanisms of particulate fouling are reasonably well understood, the interaction of particles with organic matter which is the case in most real life applications and organic fouling in general remains a challenge. Bulk organic matter such as natural organics, effluent organics and compounds like humic acid (HA) have been known for its fouling potential in membrane processes for quite some time which was confirmed by Oschmann et al. [23]. Previous studies showed that membrane fouling by such bulk organics is affected by many factors, including the hydrodynamic and operating conditions, the characteristics of the organics and the membranes, and the solution chemistry (in particular $\mathrm{pH}$, ionic strength and presence of multivalent ions) of the feed [24-26]. Naceur et al . [27] found an increase in DOC retention in a microfiltration process due to adsorption of HA onto modified Algerian clay. Lin et al . [28] also investigated the effects of HA characteristics on UF performance and found the hydrophilic fraction exhibits the worst flux decline despite little solute rejection and the molecules with the largest molecular weight $(6.5 \pm 22.6 \mathrm{kDa})$ exhibit the worst fouling. Ruohomäki [29] et al . found HA retention of 50-95 \% during UF when coagulants were used. Pre-coagulation with $\mathrm{NaCl}, \mathrm{KCl}, \mathrm{AlCl}_{3}$ and $\mathrm{FeCl}_{3}$ affected retention positively, while no severe fouling occurred. This indicates that particle interactions are important both with respect to fouling as well as retention. Further, calcium is an important parameter due to its complexation by humic materials [30, 31]. Calcium and bulk organics are both present in greywater and are hence expected to play a major role in the fouling behaviour. Yuan et al. [32] observed significant effect on fouling only for large molecular weight cut off membranes during UF of HA. The rate and extent of HA fouling was found to increase at low $\mathrm{pH}$, high ionic strength, and in the presence of calcium. Aoustin et

al. [33] discovered a strong effect of calcium concentration on HA retention in UF where aggregation due to calcium increased retention of bulk organics and reduced fouling. 
Another group of contaminants in greywater are surfactants. Surfactants have mainly been studied in the context of micellar enhanced UF, where a surfactant is added to the feed, which is later removed in form of micelles containing the pollutant [34, 35]. Only very few fouling studies can be found [36, 37] and Archer et al . [37] found an increase in flux in the critical micelle concentration ( $\mathrm{cmc}$ ) region during NF of an anionic surfactant. Hence micelle formation, much alike to aggregate formation is beneficial to membrane productivity in several studies. In our previous work, Nghiem et al. [38] found that sodium dodecyl sulfate (SDS) alters the attachment of deposits to UF membranes significantly.

Proteins are also a core constituent of greywater. Most protein fouling studies, admittedly driven by the dairy industry, use bovine serum albumin (BSA) as a model compound [39-41] and a small number of studies has been conducted on casein fouling [42]. Huisman et al . [39] found that protein-membrane interactions influence the fouling behaviour in the initial stages of filtration. In the high-fouling regime (later stages of filtration), protein-protein interactions dictate the overall performance and Jones et al. [40] found adsorption of the protein onto the membrane is greatest near the isoelectric point (IEP) of the protein ( $\mathrm{pH} 4.7$ for BSA). At higher $\mathrm{pH}$ values adsorption decreases due to increased electro-static repulsion between the protein molecules. Su et al. [41] found pore blocking and absorption into the pores the main fouling mechanism during filtration of BSA. Seeing the concentrations of protein in such studies is significantly higher than what can be expected in greywater, the direct applicability of those studies is questionable.

In this study the influence of greywater components on fouling and its impact on BPA retention is examined in a systematic manner. BPA retention is presented as a function of a wide $\mathrm{pH}$ range in order to understand the impact on BPA characteristics for a number of synthetic greywater solutions. The impact of particle, calcium, casein, surfactant sodium dodecyl sulphate and humic acid as greywater model compounds are investigated.

\section{MATERIALS AND METHODS}

\subsection{Submerged Direct Ultrafiltration Set-Up}

The filtration system used is shown in Figure 1. The membrane is submerged in a feed container of a volume of $2.25 \mathrm{~L}$ that is magnetically stirred. The peristaltic pump used in this 
study was a Masterflex Laboratory Standard (L/S) equipped with a digital variable-speed console drive. Masterflex Norprene L/S 25 tubing with an inner diameter of $4.8 \mathrm{~mm}$ was used. The pump had a variable flow rate range from 10 to $1000 \mathrm{~mL} / \mathrm{min}$. Further equipment consists of a DIN 16007 pressure gauge supplied by Dobbie and a PC-351 magnetic stirrer, with a maximum stir rate of 1200 rpm supplied by Industrial Equipment \& Control Pty Ltd.

\subsection{UF Membranes}

A ZeeWeed ${ }^{\circledR}-1$ (ZW-1) UF module supplied by Zenon Environmental, was used in this study. This module operates in an "outside-in" configuration, where a negative pressure provided by the pump induces a flow of water from outside to the inside of the membrane fibres. The ZeeWeed ${ }^{\circledR}$ membrane module is installed directly in the feed tank and works under dead end filtration conditions. The nominal pore size is $0.04 \mu \mathrm{m}$ and the membrane surface area $0.047 \mathrm{~m}^{2}$. The module is $17.5 \mathrm{~cm}$ high and $5.8 \mathrm{~cm}$ in diameter.

\subsection{Filtration and Cleaning Protocol}

The experiments were run with a synthetic greywater solution for 5-6 $\mathrm{h}$ on a set flow rate of $50 \mathrm{~mL} / \mathrm{min}$. A volume of $2250 \mathrm{~mL}$ of feed solution was prepared $16-18 \mathrm{~h}$ prior to the experiment and stirred for at least one hour at $1200 \mathrm{rpm}$. The solution was stored over night at $4^{\circ} \mathrm{C}$ and stirred for a further $30 \mathrm{~min}$ before the start of the experiment. Stirring was continuous at the maximum setting during the experiment. $\mathrm{pH}$ adjustments were carried out immediately before the experiment. The transmembrane pressure (TMP) was observed every $30 \mathrm{~min}$ as a fouling indicator. Feed and a permeate samples were taken every hour for turbidity, $\mathrm{pH}$ and conductivity measurements. These samples were then returned into the feed beaker. Other samples $(20 \mathrm{~mL})$ were taken every 1-1.5 h for calcium, $\mathrm{UV}_{254}$ absorption, TOC and BPA analysis. The $\mathrm{UV}_{254}$ measurements were undertaken immediately, the rest of the samples were stored at $4{ }^{\circ} \mathrm{C}$ until time of measurement.

Cleaning was conducted at the end of each experiment and consisted of the following protocol; 15 minutes aeration of the membrane in the feed beaker (removal of particles from the membrane); 15 min soaking in $0.5 \mathrm{~g} / \mathrm{L}$ SDS solution (removal of HA, organics); $15-30 \mathrm{~min}$ soaking in $10 \mathrm{~mL} / \mathrm{L}$ bleach solution (concentration $0.35 \% \mathrm{HOCl}$ ) during constant aeration (removes HA, organics and desorbs BPA). The membrane is rinsed after every step with purified 
water with a quality of $>18 \mathrm{M} \Omega / \mathrm{cm}$, then purified water is filtered and if the TMP pressure is $+/-1$ $\mathrm{kPa}$, the same as during purified water filtration prior to all experiments, then the cleaning procedure is considered as successful. The cleaned module is stored in purified water.

\subsection{Analytical Methods}

A Hach - Model 2100N analyser was used for turbidity measurements. Conductivity was measured with an Alpha 200 conductivity meter (CHK engineering ). A Micro 2 pH/Ion Meter was used to determine $\mathrm{pH}$. A Shimadzu UV1700 ParmaSpec UV-Visible spectrophotometer was used to measure absorbance. Samples were analyzed undiluted for absorbance at $254 \mathrm{~nm}$ for HA, which is the wavelength used for organics analysis, and at $280 \mathrm{~nm}$ for casein.

Total organic carbon (TOC) was measured using a Shimadzu TOC-V $\mathrm{V}_{\mathrm{CSH}}$ analyser. Analysis was conducted in non-purgeable organic carbon (NPOC) mode. Samples were kept at $4^{\circ} \mathrm{C}$ until analysed, and a calibration was conducted before each analysis using potassium hydrogen phthalate to produce standards of $0,2.5,5$ and $10 \mathrm{mg} / \mathrm{L}$. TOC vials were cleaned by rinsing with tap water and then soaking overnight in $1 \mathrm{M} \mathrm{NaOH}$. Vials were rinsed three times with deionised water, baked in an oven over night at $250^{\circ} \mathrm{C}$, and stored in clean glass beakers and covered with aluminium foil to prevent contamination.

A Varian AA- 300 Plus Atomic Absorption Spectrometer was used to measure the calcium concentration in the samples. The optimal working range of the instrument for calcium is $0.01-3 \mathrm{mg} / \mathrm{L}$. The instrument runs with an oxidizing nitrous oxide - acetylene flame, a lamp current of $10 \mathrm{~mA}$, a wavelength of $422.7 \mathrm{~nm}$ and a slit width of $0.5 \mathrm{~nm}$. Prior to the analysis a calibration with a $0.5,1,2,3 \mathrm{mg} / \mathrm{L}$ standard solution prepared from a $1000 \mathrm{mg} / \mathrm{L} \mathrm{Ca}^{2+}$ solution has been implemented.

A Shimadzu HPLC-UV system was used to determine the BPA concentration in the UF permeate samples. A reverse phase C-18 drug discovery Supelco column was used for the analysis. For the Bisphenol A analysis the pump operated at $1 \mathrm{~mL} / \mathrm{min}$ and the wavelength of the UV detector was set to $280 \mathrm{~nm}$. The injection volume was $50 \mu \mathrm{L}$ and analysis time $25 \mathrm{~min}$. Eluent A contains $80 \%$ acetonnitrile and $20 \%$ water and eluent B contains $20 \%$ acetonnitrile and $80 \%$ water buffered at $\mathrm{pH} 4.3$ using $25 \mathrm{mM} \mathrm{KH}_{2} \mathrm{PO}_{4}$. 


\subsection{Greywater Compostion}

The following model components were selected to constitute the synthetic greywater solutions used in the experiments.

Kaoline was chosen as a representative of suspended inorganic solids. Kaolin is a form of natural clay and contains a mineral content of $\sim 97 \%$ Kaolinite $\left(\mathrm{Al}_{2} \mathrm{O}_{3}-2 \mathrm{SiO}_{2}-2 \mathrm{H}_{2} \mathrm{O}\right)$. Kaolinites have hydrophilic surface OH groups, the average particle size of kaolin is $\sim 3.4 \mu \mathrm{m}$, the specific surface area is $10-20 \mathrm{~m}^{2} / \mathrm{g}$ and the density is $4000 \cdot 10^{6} \mathrm{mg} / \mathrm{m}^{3}$ [43].

Cellulose is an organic fibre and one of many polymers found in nature. Cellulose is insoluble in water and made of 2000-14000 repeat units of the monomer D-glucose. Cellulose is found in plants as microfibrils (2-20 nm diameter and 100 - $40000 \mathrm{~nm}$ long). The Cellulose used in the experiments had an average particle size of $\sim 20 \mu \mathrm{m}$, consists of $40.54 \% \mathrm{C}$ and a density of $1500 \cdot 10^{6} \mathrm{mg} / \mathrm{m}^{3}$.

Humic Acid (HA) was chosen to represent the dissolved organic loading in the experiments. HA is a component of natural organic matter that is present in all natural waters and also in wastewater [44]. The structure of HA changes with solution $\mathrm{pH}$ and salt concentration [43]. The HA used in the experiments was Sigma Aldrich HA. The recorded elementary composition in literature is $60 \% \mathrm{C}, 4.47 \% \mathrm{H}, 34.5 \% \mathrm{O}, 0.96 \% \mathrm{~N}$ [45]. The measured carbon concentration is lower at about 35-40 \% (20mg/L HA $\cong 6.22 \mathrm{mg} / \mathrm{L}$ TOC).

Sodium dodecyl sulphate (SDS) $\left(\mathrm{CH}_{3}\left(\mathrm{CH}_{2}\right)_{11} \mathrm{OSOO}_{3} \mathrm{Na}\right)$, also known as sodium lauryl sulphate, is an ionic detergent that is commonly found in household products such as shampoos [46]. The molecule has a tail of 12 carbon atoms, attached to a sulphate group, giving the molecule the amphiphilic properties required of a detergent. SDS has a high foaming capacity and a critical micelle concentration (CMC) of $8.1 \mathrm{mM}$ in water $\left(25^{\circ} \mathrm{C}\right)$, while the $\mathrm{CMC}$ decreases in the presence of salt from $3.82 \mathrm{mM}(0.02 \mathrm{M} \mathrm{NaCl})$ to $0.0083 \mathrm{mM}(0.4 \mathrm{M} \mathrm{NaCl})$ [47].

Casein was chosen to represent the nitrogen and protein fraction of the greywater

solution. Proteins are commonly used in shampoos, the most commonly used proteins being keratin and milk proteins. Casein is the major protein in milk $\sim 80 \%$ of the total protein content. The nitrogen content of milk is distributed among caseins (76\%), whey proteins (18\%), and nonprotein nitrogen (NPN) (6\%). The principal casein fractions are alpha (s1) and alpha (s2)- 
caseins, ß -casein, and kappa-casein. The molecular weight is between 19000 and $25000 \mathrm{~g} / \mathrm{mol}$ depending on the fraction. Most, but not all, of the casein proteins exist in a colloidal particle known as the casein micelle. Colloidal calcium phosphate (CCP) acts as a cement between the hundreds or even thousands of submicelles that form the casein micelle. Binding may be covalent or electrostatic. Calcium plays an important role in stabilizing the casein micelle. The

removal of $\mathrm{Ca}^{2+}$ leads to reversible dissociation of casein without micellular disintegration, while $\mathrm{Ca}^{2+}$ also leads to aggregation.

The chemicals used for preparing the synthetic greywater solution are analytical grade chemicals. The chemicals used were sodium chloride (BDH Chemicals), sodium bicarbonate, calcium chloride and kaolin (Ajax Finechem), cellulose, HA, sodium dodecyl sulfate (SDS), casein, Bisphenol A (BPA) (all Sigma Aldrich). $1 \mathrm{M} \mathrm{HCl}$ and $1 \mathrm{M} \mathrm{NaOH}$ were used for $\mathrm{pH}$ adjustment.

For stock solutions, $50 \mathrm{~g} / \mathrm{L}$ of casein was prepared in $1 \mathrm{M} \mathrm{NaOH}$ solution and $1 \mathrm{~g} / \mathrm{L}$ of $\mathrm{BPA}$ was prepared in pure methanol. These solutions were kept at $4^{\circ} \mathrm{C}$ and were used to prepare the experimental solution. The surfactant used for cleaning is the same surfactant (Sigma Aldrich SDS) as used in the synthetic greywater solution. The used bleach is common household bleach (Home Brand Regular Bleach, Woolworth Australia). The active constituent is 3.5\% sodium hypochlorite.

\section{RESULTS AND DISCUSSION}

\subsection{BPA Retention}

Synthetic greywater composed of $100 \mathrm{mg} / \mathrm{L}$ kaolin and cellulose as inorganic and organic particulate, $20 \mathrm{mg} / \mathrm{L}$ humic acid as bulk organic, $10 \mathrm{mM} \mathrm{NaCl}$ as background electrolyte and 1 $\mathrm{mM} \mathrm{NaHCO}$ as buffer as well as two different $\mathrm{CaCl}_{2}$ concentrations $(0.5$ and $4 \mathrm{mM})$ was spiked with $1 \mathrm{mg} / \mathrm{L}$ BPA to examine trace contaminant removal efficiency. The experiment was conducted as a function of $\mathrm{pH}$ to investigate the impact of compound speciation, namely the dissociation at a $\mathrm{pH}$ of about 10 , on retention. The speciation of $\mathrm{BPA}$ as a function of $\mathrm{pH}$ is shown in Figure 2. At low and neutral pH BPA exists predominantly in its neutral form HO$\mathrm{C}_{15} \mathrm{H}_{14}-\mathrm{OH}$, while above $\mathrm{pH} 10.1$ the negatively charged specie $\mathrm{HO}-\mathrm{C}_{15} \mathrm{H}_{14}-\mathrm{O}^{-}$predominates. Speciation has been shown to be important in the NF of BPA where retention increased 
significantly at $\mathrm{pH} 11$ over $\mathrm{pH} 6$ presumably due to charge repulsion [13]. For estrogens speciation affects adsorption to the membrane and subsequently retention, while during initial stages of filtration retention is high at low $\mathrm{pH}$ (due to adsorption), retention is low at high $\mathrm{pH}$ if the pore size is sufficiently large [48]. After adsorption at equilibrium is reached, adsorbing compounds (low $\mathrm{pH}$ ) are retained substantially less than charged species (high $\mathrm{pH})$ [13, 49].

In this situation with a number of suspended and dissolved solutes in the synthetic greywater, the BPA retention is constant between $\mathrm{pH} 4-9$ and then decreasing till there is no retention at $\mathrm{pH} 12$ (see Figure 3). This trend is identical for both calcium concentrations investigated. The retention at low and medium $\mathrm{pH}$ is surprisingly high for UF with about $40 \%$ at low and 30\% at high calcium concentration. The retention of BPA is presumably attributed to the adsorption of BPA on particulate or organic matter, which is then retained by the membrane or due to adsorption on the membrane itself. Those mechanisms were also recorded by Wintgens et al. [14].

An identical trend is shown in Figure 4 permeate BPA concentration is constant between $\mathrm{pH}$ 4-9 and then a steep increase in BPA concentration between $\mathrm{pH}$ 9-12 is observed. At high $\mathrm{pH}$ values $(>9)$ a release of the adsorbed fraction to the liquid phase takes place, shown in lower retention and higher BPA permeate concentrations. Adsorption to the membrane, organics and particulates of BPA occurs at $\mathrm{pH}$ values below the $\mathrm{pK}_{\mathrm{a}}$ value $\left(\mathrm{pK}_{\mathrm{a}}\right.$ of BPA is between 9.6 to 10.2 [12]), while desorption is starting to occur at $\mathrm{pH}$ values in the range of the $\mathrm{pKa}$ value and above, until there is no further adsorption observed at $\mathrm{pH}$ 12. Clara et al. [11] reported the same effect during absorption of BPA and other EDCs onto sewage sludge. The $\mathrm{pH}$ dependence of BPA speciation shows a similar trend to the $\mathrm{pH}$ dependence of BPA retention with retention decreasing dramatically at high $\mathrm{pH}$. As expected adsorption is low were charge repulsion is higher (negatively charged membrane and BPA at high $\mathrm{pH}$ ).

To distinguish between BPA adsorption onto the membrane and adsorption onto particulate matter, purified water containing $1 \mathrm{mg} / \mathrm{L} \mathrm{BPA}$ was filtered for one hour at each $\mathrm{pH}$ value from 4-12. The results are summarized in Table 4. The retention is similar (about 30\%) to results obtained at high calcium concentration $(4 \mathrm{mM})$. This indicates that adsorption on the membrane is a strong component, although the difference of adsorption to the membrane and partitioning into organic and inorganic solutes is difficult to distinguish. In the presence of organic matter the membrane surface properties change $[50,51]$ and hence adsorption would be 
expected to vary also. Further, in the presence of organic matter the adsorption of trace organics on particulate matter varies, in the case of kaolin and natural organics the estrone adsorption increases [15]. Organic matter adsorbs to inorganic particles in the aqueous environment and trace organic contaminants tend to partition into some bulk organics through an affinity process. Calcium plays a bridging role between negatively charged organic matter and negatively charged particulates as well as membranes. It hence substantially influences the aggregation and stability of such mixtures and the surface charge of the resulting particulates. Examining similar solutes for the adsorption of estrone (at a lower concentration of $100 \mathrm{ng} / \mathrm{L}$ ) the measured adsorption was 114-176 ng/g for hematite, kaolin, bentonite and cellulose. Adsorption onto natural organic matter or HA was $1750 \mathrm{ng} / \mathrm{g}$ and on activated sludge $6 \mathrm{ng} / \mathrm{g}$ [15]. Those values are affected significantly by the available surface area as well as solute concentration, however, one would expect that the presence of organic matter increases adsorptive interactions. The role of calcium in these interactions remains unclear. Seeing that calcium interacts at charge moieties of the molecules, one would expect hydrophobic interactions to increase as those charged groups are occupied.

BPA was also spiked in the experiments containing casein to examine the influence of organics. The BPA permeate concentration and the BPA retention at different casein concentrations are shown in Figure 5. Casein has no significant influence on BPA retention, the retention is stable at about $40-45 \%$ in all experiments. BPA is probably retained due to absorption onto particles, HA and the membrane as described above. Casein concentration does not appear to be limiting the interaction with BPA and has therefore no influence on retention.

Membrane fouling complicates the observations further. If pores are blocked, a 'dynamic membrane' may form and retain more solutes than in a clean state. This was shown to have a significant effect in the UF of activated sludge (biologically inactive) where retention increased significantly [15]. In the following section the fouling of UF membranes for different synthetic greywater solutions (with varying composition) is examined and related to BPA retention.

\subsection{Transmembrane Pressure increase during Greywater Filtration}

The driving force of filtration, transmembrane pressure increases, when the membrane fouls as the permeate flow is set constant. Figure 6 and Figure 7 show transmembrane pressure 
increase for a range of greywater mixtures to evaluate the main contributors to membrane fouling and explain some of the effects observed in BPA retention.

Figure 6 investigates the impact of calcium and HA on fouling. The first column shows negligible fouling by particulates in the absence of HA. The addition of $20 \mathrm{mg} / \mathrm{L}$ HA in the fourth set shows a significant amount of pressure increase, while this decreases if either particles (column 2) or calcium (column 3) are removed. Those results indicate the importance of the interplay of the different solutes and the fact that it is HA and calcium that act as a glue to hold the particle cake to the membrane. Very interestingly, if the calcium concentration is increased to $4 \mathrm{mM}$ the pressure increase is inhibited as in the absence of HA. This phenomenon is similar to those observed by Waite [52] and Aoustin [33] and can be attributed to aggregation at a sufficiently high calcium concentration that results in a looser deposit.

It is interesting to note the correlation between pressure increase and hence fouling and $\mathrm{BPA}$ retention. The retention of $\mathrm{BPA}$ is $10 \%$ higher when the pressure increase is the most significant at the $0.5 \mathrm{mM}$ (or $20 \mathrm{mg} / \mathrm{L}$ ) calcium concentration. BPA due to its molecular dimensions (see Table 3) of about $1 \mathrm{~nm}$ should not be retained by a membrane with a nominal pore size of about $40 \mathrm{~nm}$. It is clear that the retention of such a small contaminant has to be due to adsorption to the membrane, a solute or due to capture in a membrane deposit.

Figure 7 shows the impact of some organic molecules on fouling. All experiments contain kaolin and cellulose as in previous tests. In the first column the HA concentration is increased from 20 to $80 \mathrm{mg} / \mathrm{L}$ as shown in Figure 6, which more than doubles the transmembrane pressure. The addition of SDS does not influence fouling in the presence of calcium but causes an increase of fouling in the absence of calcium. Most likely those changes affect micelle formation and hence permeability of the boundary layer. Casein increases pressure, but decreases substantially in the absence of HA. Those results indicate that even in the presence of substantial amount of other organics and particulates, $\mathrm{HA}$ and calcium are the main determinants in membrane fouling. To investigate those effects in a more systematic and controlled manner, the concentrations of each compound are varied. Those results are shown in Figure 8.

Fouling increases with an increase of particle concentration. While the initial increase is steep, this levels out after about $100 \mathrm{mg} / \mathrm{L}$. The initial increase can be explained with an increase in the particle deposit on the membranes, while the leveling off can be explained with the fact 
that the membrane is mounted vertically and after a certain amount of deposit, gravity will limit the cake thickness. The calcium contribution to fouling peaks at about $20 \mathrm{mg} / \mathrm{L}$ and then drops steadily, presumably as it's contribution to aggregation of solutes increases. The fouling contribution of casein is small, despite the relatively high concentration. In the presence of HA this contribution is identical but $\mathrm{HA}$ adds $10 \mathrm{kPa}$ to the transmembrane pressure. Sodium dodecyl sulphate (SDS) has little to contribute to fouling and effects are comparable to casein. HA is the main contributor (note the different y-axis scale) to fouling with a direct correlation between concentration and pressure increase. HA is also added in the lowest concentration compared to other compounds.

The implications of these findings are that separation of greywater from different origins may be sensible with regards to cleaning. HA in greywater would mostly originate from kitchen waste and hence contribute mostly to what Ramon et al. [1] describe as high strength greywater. If low strength greywater is treated then a very economic performance can be expected. Further work is required to determine the effects of common surfactants and personal care products on the cleaning capacity of membranes.

\section{CONCLUSIONS}

Summarizing, BPA retention occurs due to absorption onto the membrane and onto particulate or organic matter at $\mathrm{pH}$ values below the $\mathrm{pK}_{\mathrm{a}}$ value of $\mathrm{BPA}$ and decreases at $\mathrm{pH}$ values around and above the $\mathrm{pK}_{\mathrm{a}}$ value. The $\mathrm{BPA}$ retention is higher in the experiments containing low calcium concentration. Casein has no influence on BPA removal.

\section{[needs more]}

\section{ACKNOWLEDGEMENTS}

Zenon Environmental (Canada) is thanked for the provision of membrane research modules and Shimadzu (Sydney, Australia) for the loan of a HPLC system. The authors would like to acknowledge Gosford City Council for provision of project funding, and Deutscher Akademischer Austausch Dienst (DAAD, Bonn, Germany) for providing a scholarship for Nadine Oschmann.

This project was also partly supported by the International Science Linkages programme 
established under the Australian Government's innovation statement Backing Australia’s Ability.

It is funded by the Commonwealth Department of Education Science and Training for the project

OzAquarec: Integrated Concepts for Reuse of Upgraded Wastewater in Australia (CG030025).

\section{REFERENCES}

1. Ramon, G., M. Green, R. Semiat, and C. Dosoretz, Low strength graywater characterization and treatment by direct membrane filtration. Desalination, 2004. 170: p. 241-250.

2. $\quad$ Metcalf and Eddy, Wastewater engineering treatment, disposal and reuse. 3th ed. 1991, Singapore: McGraw-Hill book co. 1334.

3. Jefferson, B., A. Palmer, P. Jeffrey, R. Stuetz, and S. Judd, Grey water characterisation and its impact on the selectilon and operation of technologies for urban reuse. Water Science And Technology, 2004. 50(2): p. 157-164.

4. Eriksson, E., K. Auffarth, M. Henze, and A. Ledin, Characteristics of grey wastewater. Urban Water, 2002. 4(1): p. 85-104.

5. Sumpter, J.P. and A.C. Johnson, Lessons from endocrine disruption and their application to other issues concerning trae organics in the aquatic environment. Environmental Science \& Technology, 2005. 39(12): p. 4321-4332.

6. Johnson, A.C. and J.P. Sumpter, Removal of endocrine-disrupting chemicals in activated sludge treatment works. Environmental Science \& Technology, 2001. 35: p. 4697-4703.

7. Boxall, A.B.A., C.J. Sinclair, K. Fenner, D. Kolpin, and S.J. Maund, When synthetic chemicals degrade in the environment. Environmental Science \& Technology, 2004. 38: p. 369A-375A.

8. Higgins, J., J. Warnkena, P.P. Sherman, and P.R. Teasdale, Survey of users and providers of recycled water: quality concerns and directions for applied research. Water Research, 2002. 36: p. 5045-5056.

9. Vilchez, J.L., A. Zafra, A. Gonzalez-Casado, E. Hontorio, and M. del Olmo, Determination of trace amounts of bisphenol F, bisphenol A and their diglycidyl ethers in wastewater by gas chromatography-mass spectrometry. Analytica Chimica Acta, 2001. 431(1): p. 31-40.

10. Zafra, A., M. del Olmo, B. Suarez, E. Hontoria, A. Navalon, and J.L. Vilchez, Gas chromatographic-mass spectrometric method for the determination of bisphenol A and its chlorinated derivatives in urban wastewater. Water Research, 2003. 37(4): p. 735-742.

11. Clara, M., B. Strenn, E. Saracevic, and N. Kreuzinger, Adsorption of bisphenol-A, 17 beta-estradiole and 17 alpha-ethinylestradiole to sewage sludge. Chemosphere, 2004. 56(9): p. 843-851.

12. Staples, C.A., P.B. Dorn, G.M. Klecka, S.T. O'Block, and L.R. Harris, A review of the environmental fate, effects, and exposures of bisphenol A. Chemosphere, 1998. 36(10): p. 2149-2173.

13. Nghiem, D.L., A.I. Schäfer, and M. Elimelech, Nanofiltration of hormone mimicking trace organic contaminants. Separation Science and Technology, 2005. 40: p. 26332649.

14. Wintgens, T., M. Gallenkemper, and T. Melin, Endocrine disrupter removal from wastewater using membrane bioreactor and nanofiltration technology. Desalination, 2002. 146(1-3): p. 387-391. 
15. Schäfer, A.I., M. Mastrup, and R.L. Jensen, Particle interactions and removal of trace contaminants from water and wastewaters. Desalination, 2002. 147(1-3): p. 243-250.

16. Lodge, B., S.J. Judd, and A.J. Smith, Characterisation of dead-end ultrafiltration of biotreated domestic wastewater. Journal Of Membrane Science, 2004. 231(1-2): p. 9198.

17. Yeom, I.T., Y.M. Nah, and K.H. Ahn, Treatment of household wastewater using an intermittently aerated membrane bioreactor. Desalination, 1999. 124(1-3): p. 193-203.

18. Wintgens, T., J. Rosen, T. Melin, C. Brepols, K. Drensla, and N. Engelhardt, Modelling of a membrane bioreactor system for municipal wastewater treatment. Journal of Membrane Science, 2003. 216(1-2): p. 55-65.

19. Rosenberger, S., U. Kruger, R. Witzig, W. Manz, U. Szewzyk, and M. Kraume, Performance of a bioreactor with submerged membranes for aerobic treatment of municipal waste water. Water Research, 2002. 36(2): p. 413.

20. Jiang, T., M.D. Kennedy, W.G.J. van der Meer, P.A. Vanrolleghem, and J.C. Schippers, The role of blocking and cake filtration in MIBR fouling. Desalination, 2003. 157(1-3): p. 335-343.

21. Fane, A.G., P. Beatson, and H. Li, Membrane fouling and its control in environmental applications. Water Sci. Technol., 2000. 41(10-11): p. 303-308.

22. Song, L., K.L. Chen, S.L. Ong, and W.J. Ng, A new normalization method for determination of colloidal fouling potential in membrane processes. Journal of Colloid and Interface Science, 2004. 271(2): p. 426.

23. Oschmann, N., L.D. Nghiem, and A.I. Schäfer, Fouling mechanisms of submerged ultrafiltration in greywater recycling. Desalination, 2005. 179: p. 215-223.

24. Kulovaara, M., S. Metsamuuronen, and M. Nystrom, Effects of aquatic humic substances on a hydrophobic ultrafiltration membrane. Chemosphere, 1999. 38(15): p. 3485-3496.

25. Jucker, C. and M.M. Clark, Adsorption of aquatic humic substances on hydrophobic ultrafiltration membranes. Journal Of Membrane Science, 1994. 97: p. 37-52.

26. Braghetta, A., F.A. DiGiano, and W.P. Ball, Nanofiltration of natural organic matter: $p H$ and ionic strength effects. Journal of Environmental Engineering, 1997. 123(7): p. 628641.

27. Naceur, W.M., N.A. Messaoudene, and A. Aggoun, Microfiltration reinforced adsorption of humic acids onto modified Algerian clay. Desalination, 2003. 158(1-3): p. 271-276.

28. Lin, C.F., T.Y. Lin, and O.J. Hao, Effects of humic substance characteristics on UF performance. Water Research, 2000. 34(4): p. 1097-1106.

29. Ruohomäki, K., P. Väisänen, S. Metsämuuronen, M. Kulovaara, and M. Nyström, Characterization and removal of humic substances in ultra- and nanofiltration. Desalination, 1998. 118: p. 273-283.

30. Clark, M.M. and P. Lucas, Diffusion and partitioning of humic acid in a porous ultrafiltration membrane. Journal of Membrane Science, 1998. 143(1-2): p. 13-25.

31. $\mathrm{Li}, \mathrm{Q} . \mathrm{L}$. and M. Elimelech, Organic fouling and chemical cleaning of nanofiltration membranes: Measurements and mechanisms. Environmental Science \& Technology, 2004. 38(17): p. 4683-4693.

32. Yuan, W. and A.L. Zydney, Humic acid fouling during microfiltration. Journal of Membrane Science, 1999. 157(1): p. 1-12. 
33. Aoustin, E., A.I. Schäfer, A.G. Fane, and T.D. Waite, Effect of Humic Sustance and Colloid Interactions on Ultrafiltration Behaviour. Separation and Purification Technology, 2001. 22-23: p. 63-78.

34. Baek, K., B.K. Kim, and J.W. Yang, Application of micellar enhanced ultrafiltration for nutrients removal. Desalination, 2003. 156(1-3): p. 137-144.

35. Baek, K., H.H. Lee, and J.W. Yang, Micellar-enhanced ultrafiltration for simultaneous removal of ferricyanide and nitrate. Desalination, 2003. 158(1-3): p. 157-166.

36. Childress, A.E. and M. Elimelech, Relating nanofiltration membrane performance to membrane charge (electrokinetic) characteristics. Environmental Science and Technology, 2000. 34(17): p. 3710-3716.

37. Archer, A.C., A.M. Mendes, and R.A.R. Boaventura, Separation of an anionic surfactant by nanofiltration. Environmental Science \& Technology, 1999. 33(16): p. 2758-2764.

38. Nghiem, L.D., N. Oschmann, and A.I. Schäfer, Fouling in greywater recycling by direct ultrafiltration. Desalination, 2006. 187: p. 283-290.

39. Huisman, I.H., P. Pradanos, and A. Hernandez, The effect of protein-protein and proteinmembrane interactions on membrane fouling in ultrafiltration. Journal Of Membrane Science, 2000. 179(1-2): p. 79-90.

40. Jones, K.L. and C.R. O'Melia, Protein and humic acid adsorption onto hydrophilic membrane surfaces: effects of $\mathrm{pH}$ and ionic strength. Journal Of Membrane Science, 2000. 165(1): p. 31-46.

41. Su, T.J., J.R. Lu, Z.F. Cui, B.J. Bellhouse, R.K. Thomas, and R.K. Heenan, Identification of the location of protein fouling on ceramic membranes under dynamic filtration conditions. Journal Of Membrane Science, 1999. 163(2): p. 265-275.

42. Cicek, N., H. Winnen, M.T. Suidan, B.E. Wrenn, V. Urbain, and J. Manem, Effectiveness of the membrane bioreactor in the biodegradation of high molecular weight compounds. Water Research, 1998. 32(5): p. 1553.

43. Essington, M.E., Soil and water chemistry. 2003: CRC Press.

44. Wall, N.A. and G.R. Choppin, Humic acids coagulation: influence of divalent cations. Applied Geochemistry, 2003. 18: p. 1573-1582.

45. Mao, J. and W. Hu, Structure and elemental composition of Humic acids, in Humic Substances: Structures, Properties and Uses, G. Davies and E.A. Ghabbour, Editors. 1998, Royal Society of Chemistry: Cambridge.

46. Meyer, D., Surfactant science and technology. 1988, New York: VCH Publisher Inc.

47. Hiemenz, C.P. and R. Rajagopalan, Principles of colloid and surface chemistry. 1997, New York: Marcel Dekker.

48. Schäfer, A.I., D.L. Nghiem, and T.D. Waite, Removal of the Natural Hormone Estrone from Aqueous Solutions Using Nanofiltration and Reverse Osmosis. Environmental Science \& Technology, 2003. 37(1): p. 182-188.

49. Bellona, C. and J.E. Drewes, The role of membrane surface charge and solute physicochemical properties in the rejection of organic acids by NF membranes. Journal of Membrane Science, 2005. 249(1-2): p. 227-234.

50. Childress, A.E. and M. Elimelech, Effect of solution chemistry on the surface charge of polymeric reverse osmosis and nanofiltration membranes. Journal of Membrane Science, 1996. 119: p. 253-268. 
51. Childress, A.E. and S.S. Deshmukh, Effect of humic substances and anionic surfactants on the surface charge and performance of reverse osmosis membranes. Desalination, 1998. 118: p. 167-174.

52. Waite, T.D., A.I. Schäfer, A.G. Fane, and A. Heuer, Colloidal Fouling of Ultrafiltration Membranes: Impact of Aggregate Structure and Size. Journal of Colloid and Interface Science, 1999. 212: p. 264-274.

53. Nolde, E., Greywater reuse systems for toilet flushing in multi-storey buildings - over ten years experience in Berlin. Urban Water, 2000. 1(4): p. 275-284.

54. Christova-Boal, D., R.E. Eden, and S. McFarlane, An investigation into greywater reuse for urban residential properties. Desalination, 1996. 106(1-3): p. 391-397.

55. Fresenius, W., W. Schneider, and B. Böhnke, Wastewater technology: origin, collection, treatment and analysis of wastewater. 1989, Berlin: Springer-Verlag.

56. Al-Jayyousi, O.R., Greywater reuse: towards sustainable water management. Desalination, 2003. 156(1-3): p. 181-192.

57. Pallas, PrologP/PropKa. 2000, CompuDrug Chemistry Ltd: Sedona, AZ.

58. Hyperchem, Release 7.0 for Window, Molecular modeling system. 2003, Hypercube Inc: Gainesville, FL.

59. Sohoni, P., C.R. Tyler, K. Hurd, J. Caunter, M. Hetheridge, T. Williams, C. Woods, M. Evans, R. Toy, M. Gargas, and J.P. Sumpter, Reproductive effects of long-term exposure to bisphenol A in the fathead minnow (pimephales promelas). Environmental Science \& Technology, 2001. 35: p. 2917-2925. 
Table 1: Sources of wastewater and their pollutants [53, 54]

\begin{tabular}{|l|c|l|}
\hline $\begin{array}{l}\text { Wastewater } \\
\text { source }\end{array}$ & $\begin{array}{l}\text { Share of Water } \\
\text { usage (\%) }\end{array}$ & Pollutants \\
\hline Kitchen & $6-9$ & $\begin{array}{l}\text { Oils, bacteria, dishwashing } \\
\text { detergent }\end{array}$ \\
\hline $\begin{array}{l}\text { Bathroom, showers } \\
\text { and hand basins }\end{array}$ & $\begin{array}{l}\text { Soaps, shampoos, body-fats, } \\
\text { hair, soils (occasionally lint, } \\
\text { fabric fibres, skin, urine and } \\
\text { faeces) }\end{array}$ \\
\hline $\begin{array}{l}\text { Laundry troughs } \\
\text { and washing } \\
\text { machines }\end{array}$ & $12-17$ & $\begin{array}{l}\text { Detergents, bleaches } \\
\text { occasionally oil, pains and } \\
\text { solvents) }\end{array}$ \\
\hline Toilet- flushing & $23-32$ & $\begin{array}{l}\text { Urin, faeces, toilet paper, } \\
\text { cleaning products }\end{array}$ \\
\hline
\end{tabular}

Table 2: Composition of domestic wastewater and greywater $[2,4,54-56]$

\begin{tabular}{|l|c|c|}
\hline & Blackwater & Greywater \\
\hline pH [-] & $5.9-7.7$ & $5-10.9$ \\
\hline Total solids [mg/L] & $200-1200$ & $113-2410$ \\
\hline Total dissolved solids (TDS) [mg/L] & $100-850$ & $137-1260$ \\
\hline Suspended solids (SS) [mg/L] & $24-608$ & $3.1-330$ \\
\hline BOD5 [mg/L] & $28-400$ & $33-1460$ \\
\hline TOC [mg/L] & $42-290$ & $30-880$ \\
\hline COD [mg/L] & $45-1000$ & $3.8-1380$ \\
\hline Nitrogen [mg total N/L] & $20-117$ & $0.28-74$ \\
\hline Phosphorus [mg total P/L]) & $3.2-30$ & $0.0062-74$ \\
\hline Surfactant [mg/L] & - & - \\
\hline
\end{tabular}


Table 3 Physico-chemical characteristics of Bisphenol A (BPA). Mwd Calculations made with trial Chemoffice ultra 2005 without energy minimisation and without consideration of the van der Waals radius, $\mathrm{pK}_{\mathrm{a}}$ and $\log \mathrm{K}_{\mathrm{ow}}$ were determined using software (Pallas 3.0 [57]), Dipole moment and structure was determined using software (Hyperchem [58]), EC50 for induction of vitellogenin in fish (concentration for $50 \%$ of maximum possible response) and relative potency to estradiol (E2) adapted from Sohoni et al. [59].

\begin{tabular}{|c|c|c|c|c|c|c|c|c|}
\hline Formula & $\begin{array}{c}\text { MW } \\
\text { (g/mol) }\end{array}$ & $\begin{array}{l}\text { Molecular } \\
\text { Witdh X } \\
(\mathrm{nm})\end{array}$ & $\begin{array}{c}\text { Molecular } \\
\text { Width Y } \\
\text { (nm) }\end{array}$ & $\begin{array}{l}\text { Molecular } \\
\text { Length Z } \\
\text { (nm) }\end{array}$ & $\begin{array}{c}\text { Solubility } \\
\text { in Water } \\
(\mathrm{mg} / \mathrm{L})\end{array}$ & $\mathbf{p K}_{\mathbf{a}}$ & $\begin{array}{l}\text { Log } \\
K_{\text {ow }}\end{array}$ & $\begin{array}{c}\text { Dipole } \\
\text { Moment } \\
\text { (Debye) }\end{array}$ \\
\hline $\mathrm{C}_{15} \mathrm{H}_{16} \mathrm{O}_{2}$ & 228 & 0.383 & 0.587 & 1.068 & 129 & 10.1 & 3.32 & 1.411 \\
\hline \multicolumn{4}{|c|}{ Structure } & \multicolumn{3}{|c|}{ 3D Structure Model } & $\begin{array}{r}\text { EC50 } \\
(\mu \mathrm{g} / \mathrm{L})\end{array}$ & $\begin{array}{c}\text { Relative } \\
\text { Potency to } \\
\text { E2 }\end{array}$ \\
\hline & & & & & & & 50 & 0.0004 \\
\hline
\end{tabular}

Table 4: Feed concentration, permeate concentration and retention of BPA during filtration of synthetic greywater and MilliQ water containing an intitial concentration of BPA of approximately $1 \mathrm{mg} / \mathrm{L}$.

\begin{tabular}{|c|c|c|c|c|c|c|}
\hline \multirow[b]{2}{*}{ pH ( - ) } & \multicolumn{2}{|c|}{$0.5 \mathrm{mM} \mathrm{Ca}^{2+}$} & \multicolumn{2}{|c|}{$4 \mathrm{mM} \mathrm{Ca}^{2+}$} & \multicolumn{2}{|c|}{ MilliQ water } \\
\hline & $\begin{array}{c}\text { Permeate } \\
\text { concentration } \\
(1 \mathrm{~h}) \\
(\mathrm{mg} / \mathrm{L})\end{array}$ & $\begin{array}{c}\text { Retention } \\
\text { (\%) }\end{array}$ & $\begin{array}{c}\text { Permeate } \\
\text { concentration } \\
(1 \mathbf{h}) \\
(\mathrm{mg} / \mathrm{L}) \\
\end{array}$ & $\begin{array}{c}\text { Retention } \\
\text { (\%) }\end{array}$ & $\begin{array}{c}\text { Permeate } \\
\text { concentration } \\
(1 \mathrm{~h}) \\
(\mathrm{mg} / \mathrm{L}) \\
\end{array}$ & $\begin{array}{c}\text { Retention } \\
\text { (\%) }\end{array}$ \\
\hline 4 & 0.64 & 36.03 & 0.70 & 29.1 & 0.78 & 26.7 \\
\hline 6 & 0.61 & 39.33 & 0.71 & 29.1 & 0.76 & 27.6 \\
\hline 8 & 0.63 & 37.09 & 0.72 & 27.2 & 0.78 & 28.7 \\
\hline 10 & 0.79 & 21.34 & 0.80 & 21.0 & 0.79 & 25.7 \\
\hline 12 & 1.08 & 0.00 & 1.21 & 0.00 & 1.07 & 3.90 \\
\hline
\end{tabular}


Table ???: Concentrations used in experiments

\begin{tabular}{|l|c|c|c|c|c|c|c|c|c|}
\hline Experiments & $\begin{array}{c}\mathrm{NaCl} \\
{[\mathrm{mM}]}\end{array}$ & $\begin{array}{c}\mathrm{NaHCO}_{3} \\
{[\mathrm{mM}]}\end{array}$ & $\begin{array}{c}\mathrm{CaCl}_{2} \\
{[\mathrm{mM}]}\end{array}$ & $\begin{array}{c}\mathrm{HA} \\
{[\mathrm{mg} / \mathrm{L}]}\end{array}$ & $\begin{array}{c}\text { Kaolin } \\
{[\mathrm{mg} / \mathrm{L}]}\end{array}$ & $\begin{array}{c}\text { Cellulose } \\
{[\mathrm{mg} / \mathrm{L}]}\end{array}$ & $\begin{array}{c}\text { SDS } \\
{[\mathrm{mg} / \mathrm{L}]}\end{array}$ & $\begin{array}{c}\text { Casein } \\
{[\mathrm{mg} / \mathrm{L}]}\end{array}$ & $\begin{array}{c}\text { BP A } \\
{[\mathrm{mg} / \mathrm{L}]}\end{array}$ \\
\hline 1. $\mathrm{f}\left(\mathrm{Ca}^{2+}\right)$ & 10 & 1 & variable & 20 & 100 & 100 & - & - & - \\
\hline 2. f(HA) & 10 & 1 & 0.5 & variable & 100 & 100 & - & - & - \\
\hline 3.f(Kao./Cell.) & 10 & 1 & 0.5 & 20 & variable & variable & - & - & - \\
\hline 4. f(SDS) & 10 & 1 & 0.5 & 20 & 100 & 100 & variable & - & - \\
\hline 5. f(pH) & 10 & 1 & 0.5 & 20 & 100 & 100 & - & - & 1 \\
\hline 6. f(Casein) & 10 & 1 & 0.5 & - & 100 & 100 & - & variable & - \\
\hline
\end{tabular}




\section{FIGURE CAPTIONS}

Figure 1: Experimental set-up of submerged UF rig for greywater recycling and ZW1 membrane module.

Figure 2: pH dependence of BPA speciation (Calculated based on a pKa value of 10.1 [57]).

Figure 3: BPA retention as a function of $\mathrm{pH}\left(\mathrm{Ca}^{2+} 0.5-4 \mathrm{mM}, \mathrm{HA} 20 \mathrm{mg} / \mathrm{L}\right.$, kaolin and cellulose $100 \mathrm{mg} / \mathrm{L}, \mathrm{NaCl} 10 \mathrm{mM}, \mathrm{NaHCO}_{3} 1 \mathrm{mM}$ )

Figure 4: Permeate BPA concentration as a function of $\mathrm{pH}\left(\mathrm{Ca}^{2+}\right.$ 0.5-4 mM, HA $20 \mathrm{mg} / \mathrm{L}$, kaolin and cellulose $100 \mathrm{mg} / \mathrm{L}, \mathrm{NaCl} 10 \mathrm{mM}, \mathrm{NaHCO}_{3} 1 \mathrm{mM}$ )

Figure 5: Permeate BPA concentration and retention at different casein concentrations $\mathbf{~} \mathrm{pH}$ 6.8-8.0, HA $20 \mathrm{mg} / \mathrm{L}, \mathrm{Ca}^{2+} 0.5 \mathrm{mM}$, kaolin and cellulose $100 \mathrm{mg} / \mathrm{L}$, NaCl $10 \mathrm{mM}, \mathrm{NaHCO}_{3}$ $1 \mathrm{mM})$

Figure 6: Transmembrane pressure $\Delta p$ as a function of greywater composition (all experiments contained $\mathrm{NaCl} 10 \mathrm{mM}$ and $\mathrm{NaHCO}_{3} 1 \mathrm{mM}$, pH 8)

Figure 7: Transmembrane pressure $\Delta p$ as a function of greywater composition (all experiments contained kaolin and cellulose $100 \mathrm{mg} / \mathrm{L}, \mathrm{NaCl} 10 \mathrm{mM}$ and $\mathrm{NaHCO}_{3} 1 \mathrm{mM}, \mathrm{pH}$ 8). Note that scale is 2.5 times larger than Figure 6.

Figure 8: Transmembrane pressure $\Delta p$ as a function of contaminants concentration for $A$ : Particles, B: Calcium, C: Casein, D: Sodiumdodecyl sulphate, E: Humic acid. (all experiments contained $\mathrm{NaCl} 10 \mathrm{mM}$ and $\mathrm{NaHCO}_{3} 1 \mathrm{mM}$ ) 
Figure 1

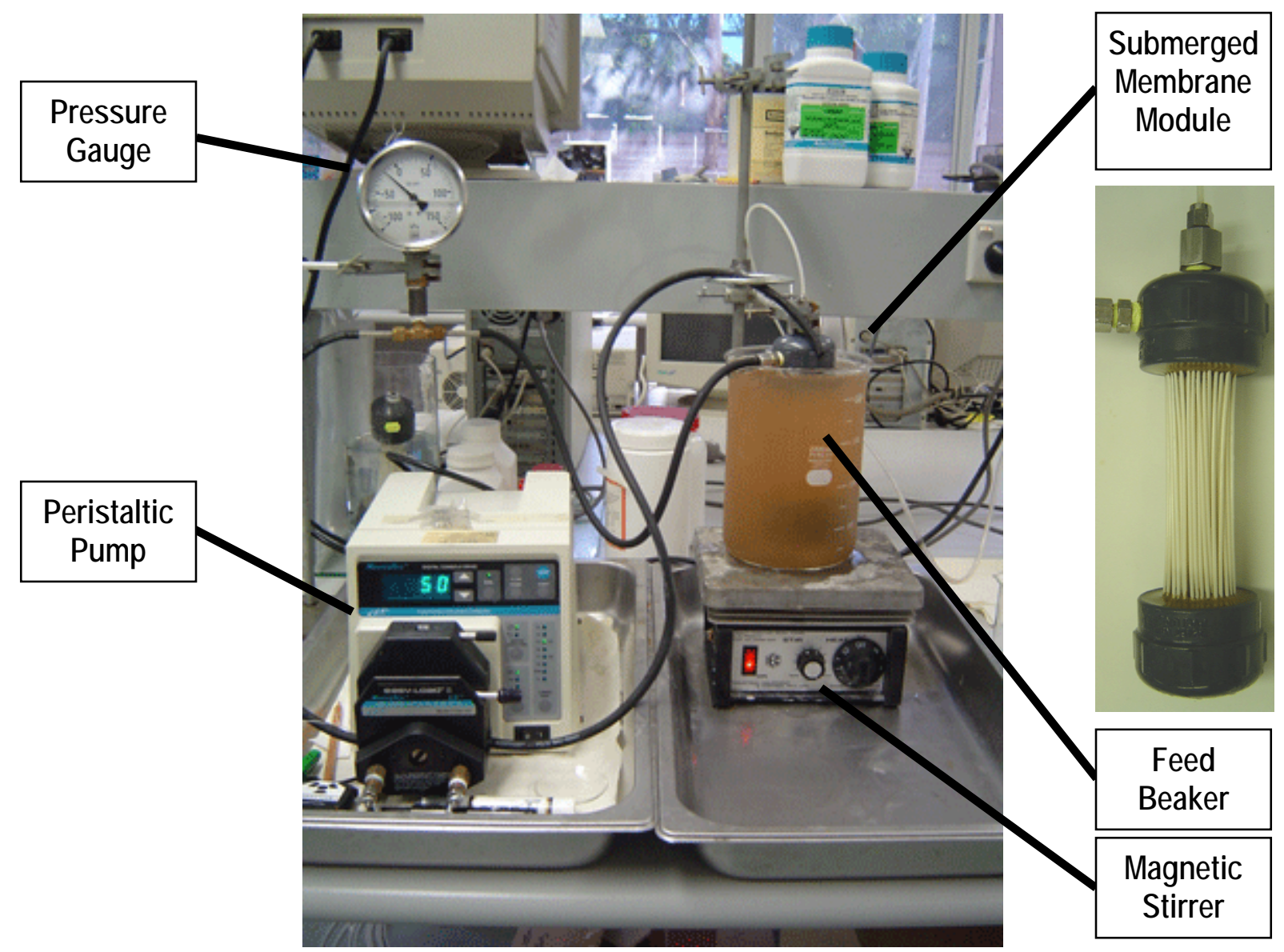


Figure 2

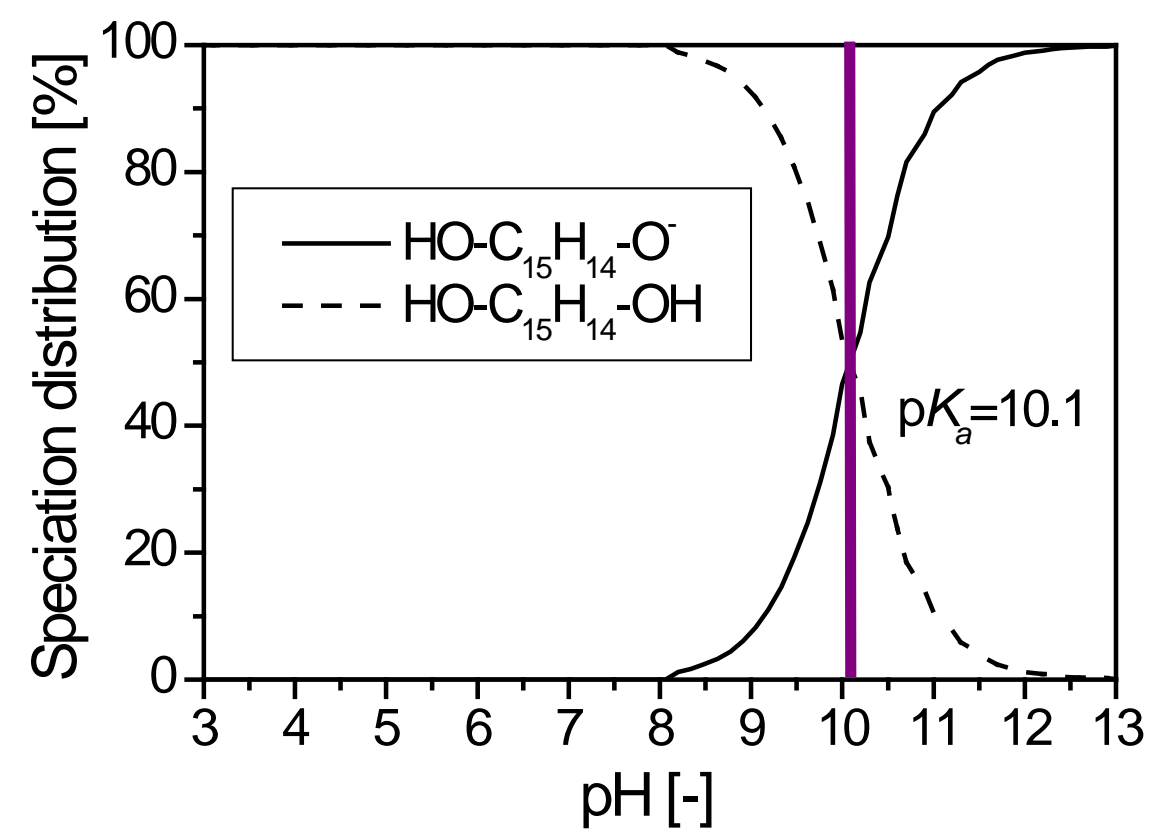


Figure 3

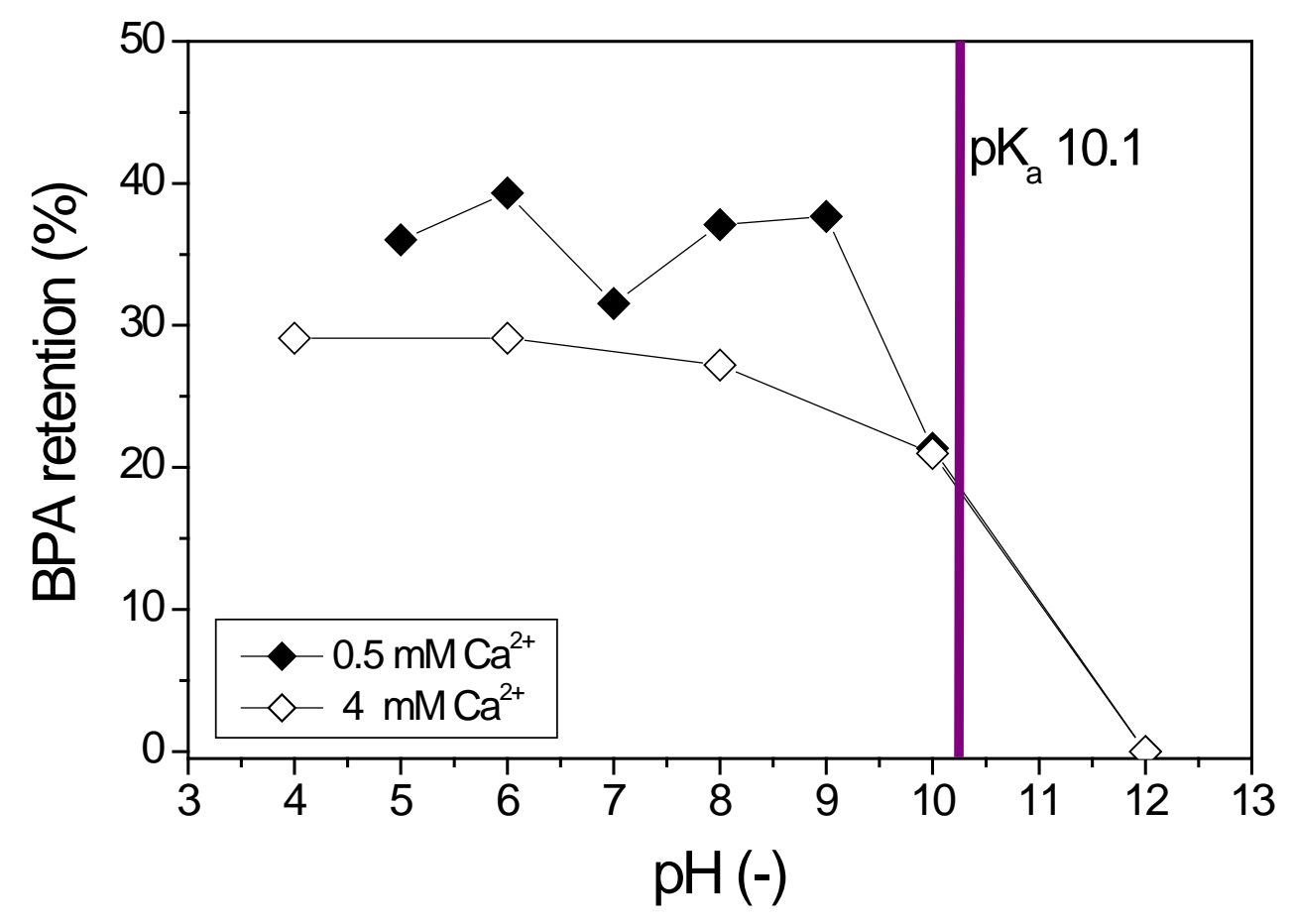


Figure 4

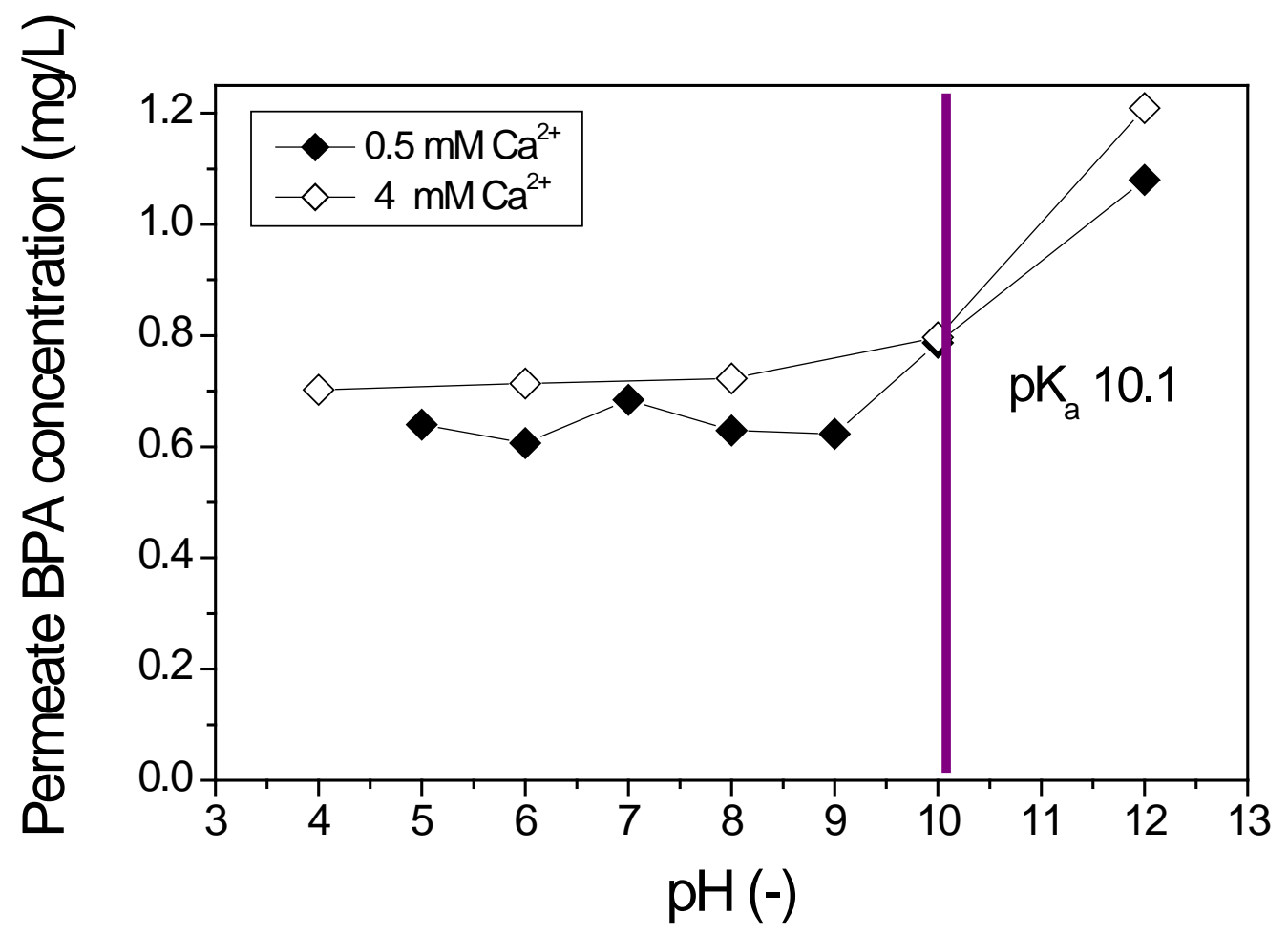


Figure 5

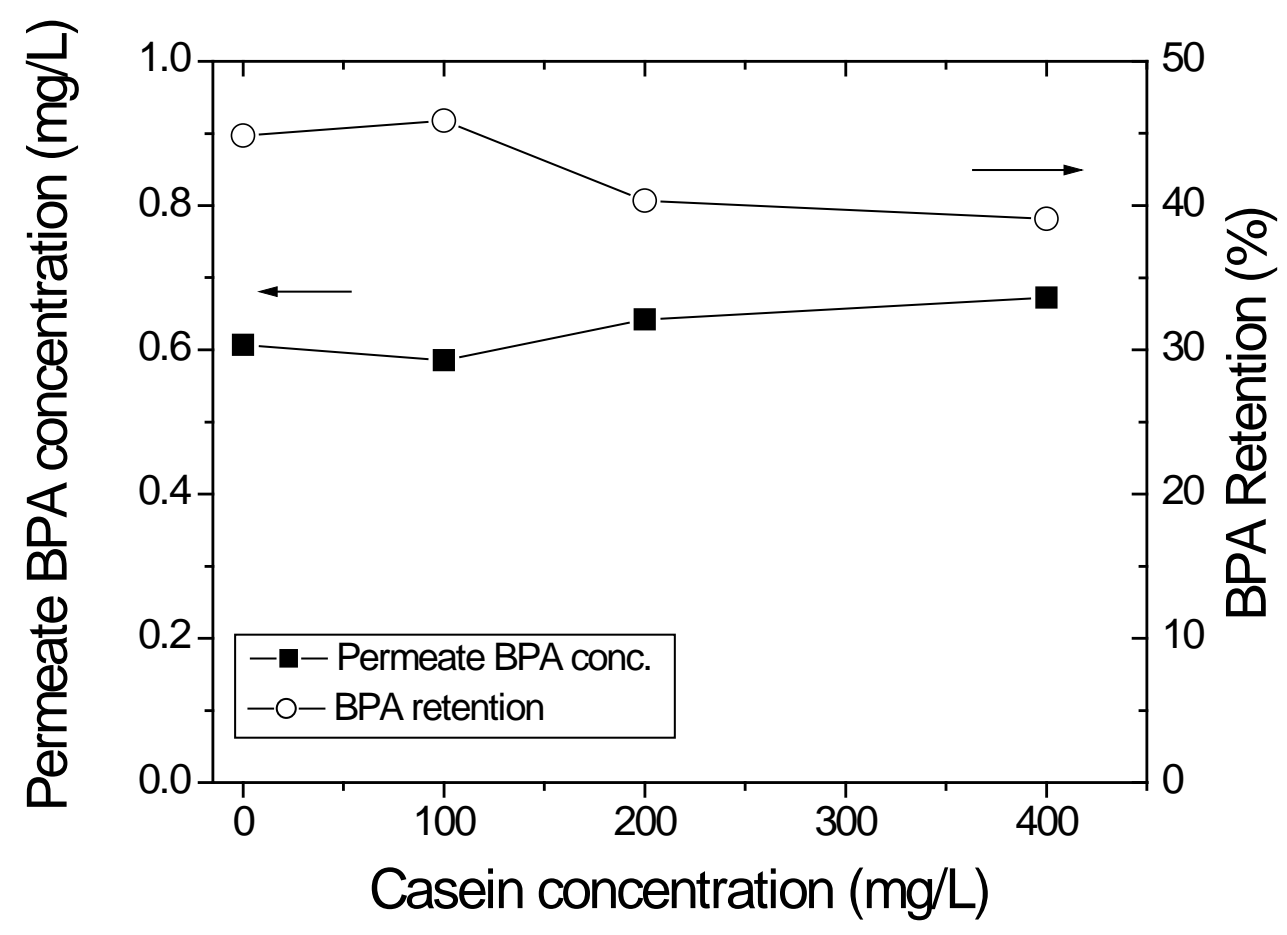


Figure 6

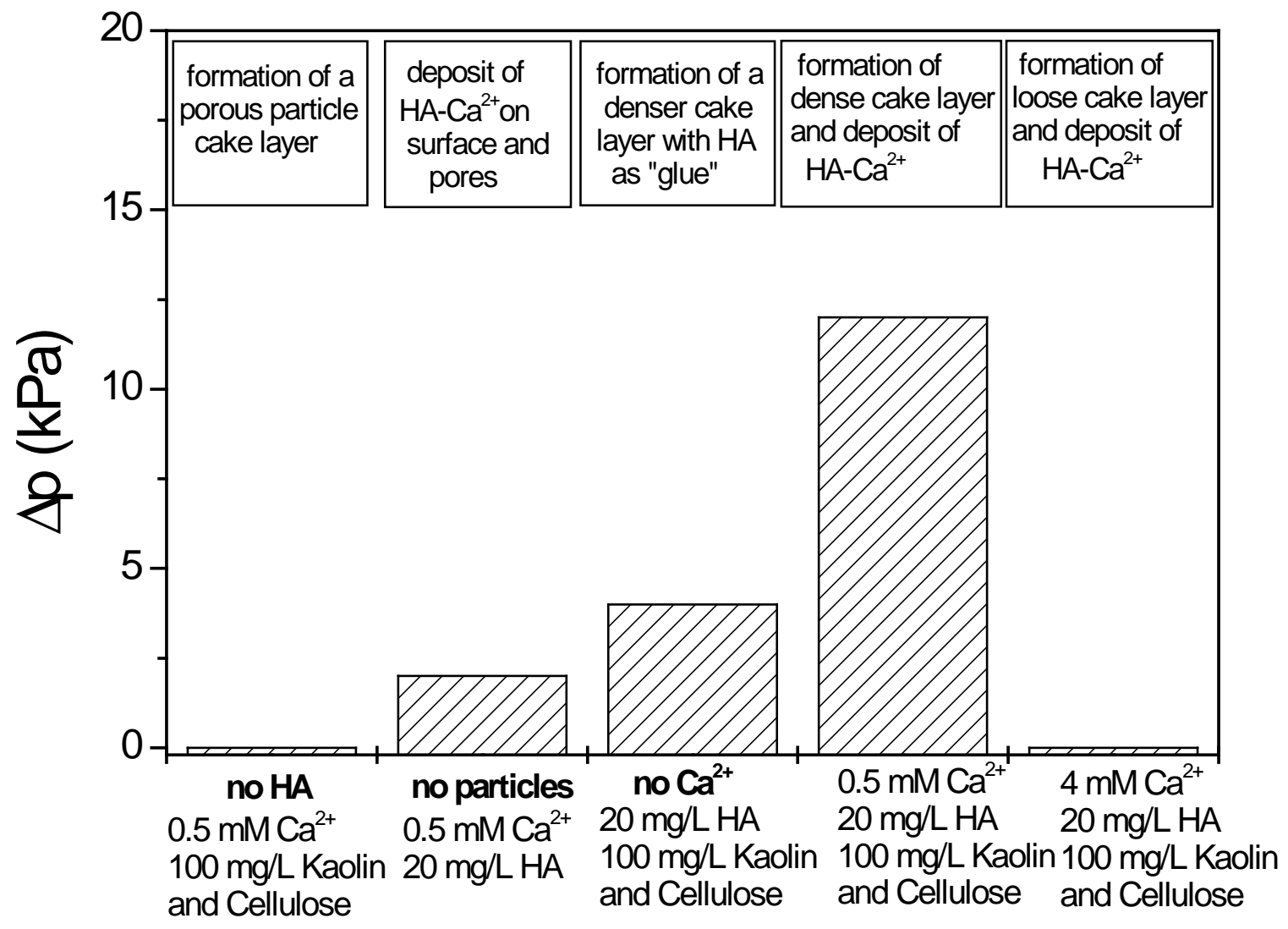


Figure 7

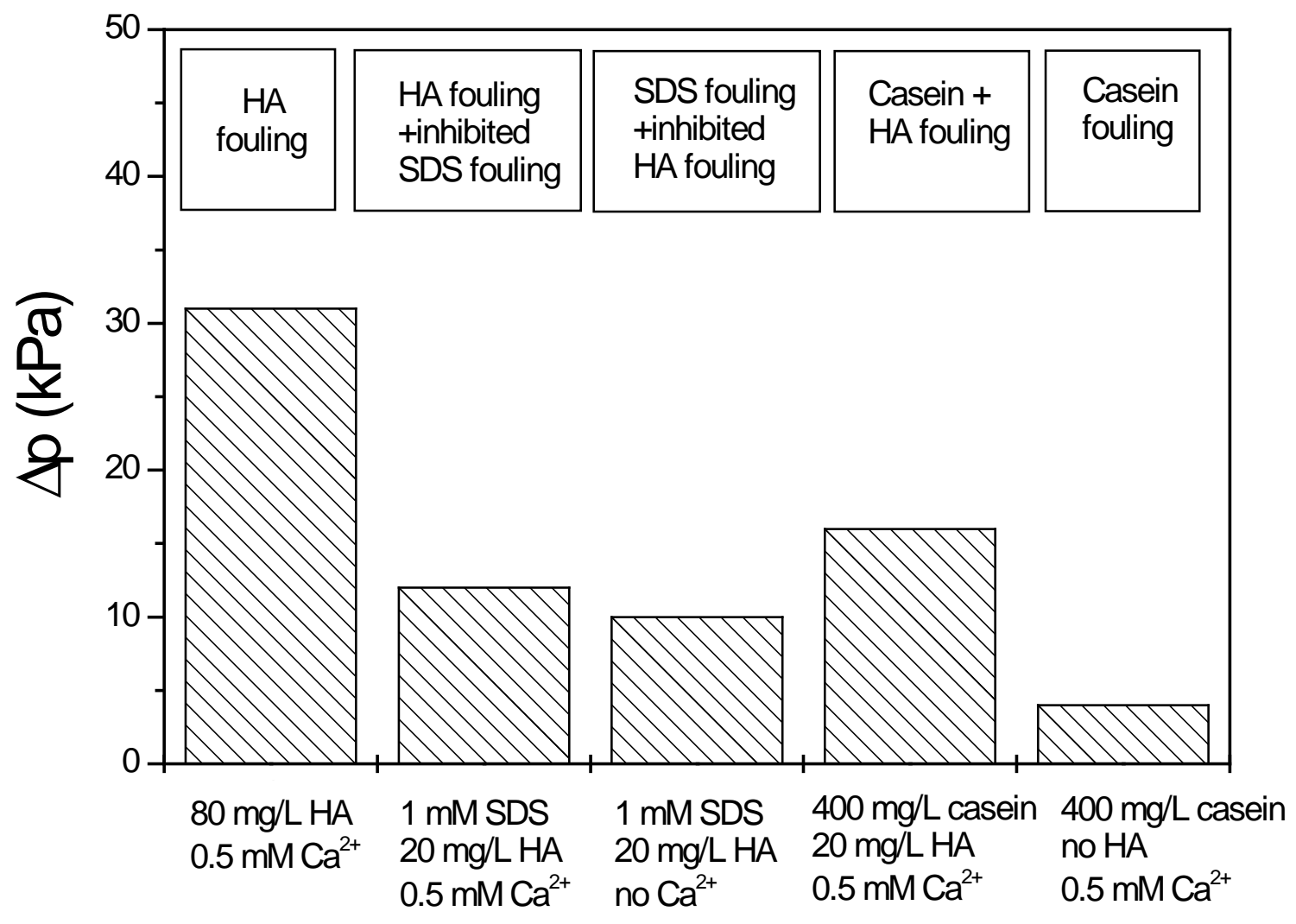


Figure 8
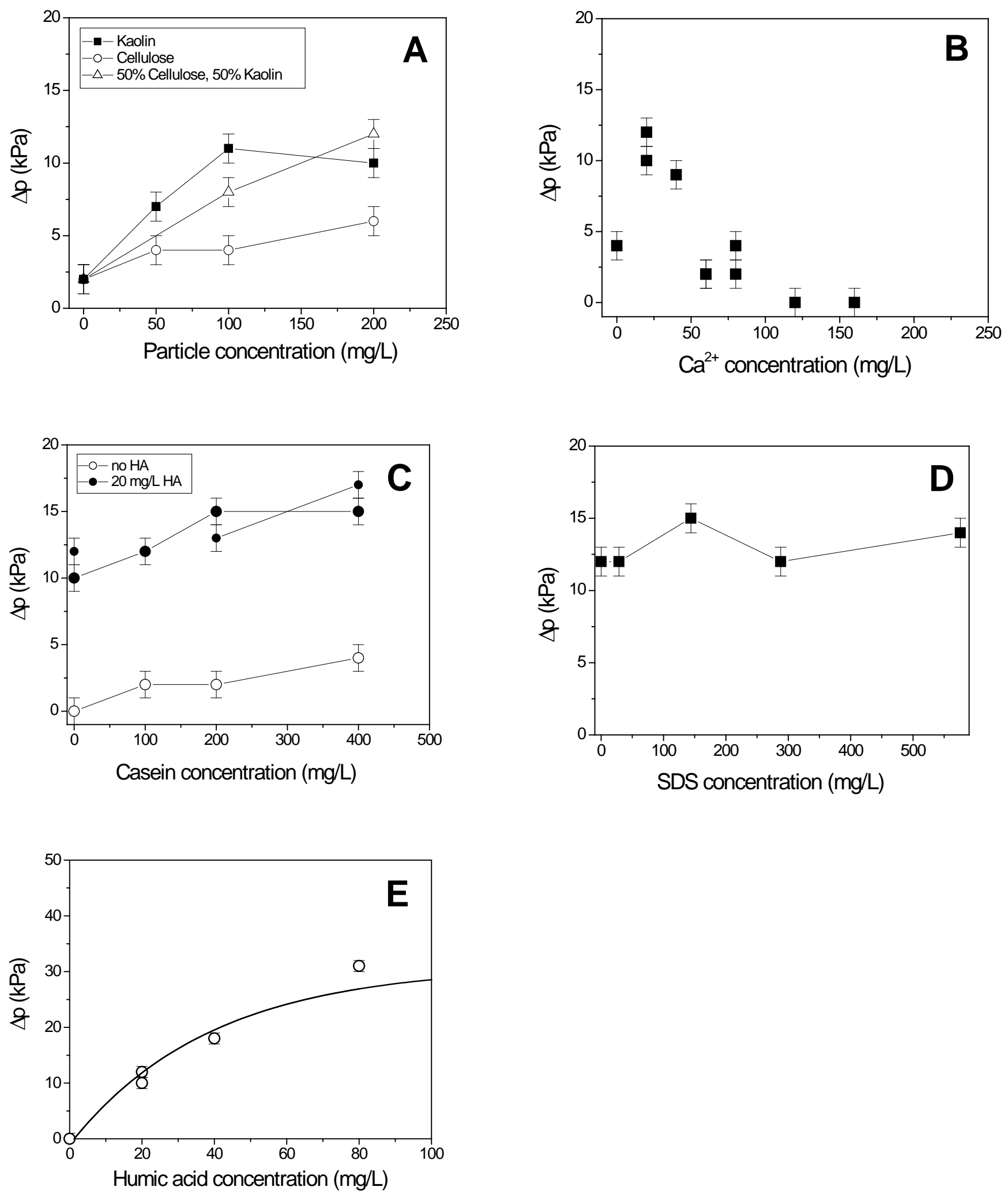
